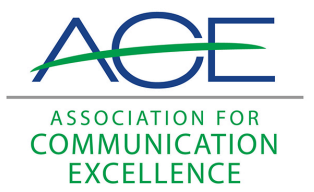

Journal of Applied Communications

\title{
Understanding Consumer Intent to Buy Local Food: Adding Consumer Past Experience and Moral Obligation Toward Buying Local Blueberries in Florida Within the Theory of Planned Behavior
}

\author{
Jessica Holt \\ University of Georgia \\ Joy N. Rumble \\ University of Florida \\ Ricky Telg \\ University of Florida
}

See next page for additional authors

Follow this and additional works at: https://newprairiepress.org/jac

Part of the Agricultural Education Commons, and the Other Communication Commons (c) (i) (3)

This work is licensed under a Creative Commons Attribution-Noncommercial-Share Alike 4.0 License.

\section{Recommended Citation}

Holt, Jessica; Rumble, Joy N.; Telg, Ricky; and Lamm, Alexa (2018) "Understanding Consumer Intent to Buy Local Food: Adding Consumer Past Experience and Moral Obligation Toward Buying Local Blueberries in Florida Within the Theory of Planned Behavior," Journal of Applied Communications: Vol. 102: Iss. 2. https://doi.org/10.4148/1051-0834.2203

This Research is brought to you for free and open access by New Prairie Press. It has been accepted for inclusion in Journal of Applied Communications by an authorized administrator of New Prairie Press. For more information, please contact cads@k-state.edu. 


\title{
Understanding Consumer Intent to Buy Local Food: Adding Consumer Past Experience and Moral Obligation Toward Buying Local Blueberries in Florida Within the Theory of Planned Behavior
}

\begin{abstract}
Buying local food has become an increasingly popular way for consumers to engage with those who grow their food; however, research has shown a specific audience tends to buy local food due to individualspecific barriers. To better understand what motivates consumers to buy local food the Theory of Planned Behavior was used as a way to potentially predict consumers' behavior toward buying locally grown blueberries. Also, the variables of past experience and self-identity/moral obligation toward buying local food were introduced to the model since both variables may increase the predictability of the Theory of Planned Behavior model in certain food-related behaviors. This study used an online survey completed by 1,122 respondents, from a sample frame of all consumers in Florida. The study used a non-probability sample of an opt-in panel, and weighting procedures were applied to the data to account for coverage errors associated with using a non-probability sample. The interaction of consumers' past experience and self-identity/moral obligation was found to help explain consumers' intention to buy locally grown blueberries when added to the Theory of Planned Behavior. The Theory of Planned Behavior was shown to predict consumers' intention to buy locally grown blueberries; however, their intent was better explained with the inclusion of the variables of past experience and self-identity/moral obligation toward buying local blueberries. Recommendations for future research and application include future research into other variables that may impact buying behavior and inclusion of these variables in future communication efforts focused on consumers buying and engaging with local food.
\end{abstract}

\section{Keywords}

theory of planned behavior, moral obligation, past experience, local food

Cover Page Footnote/Acknowledgements

This research was funded by a USDA Specialty Crop Block Grant and the University of Florida.

\section{Authors}

Jessica Holt, Joy N. Rumble, Ricky Telg, and Alexa Lamm 


\section{Understanding Consumer Intent to Buy Local Food: Adding Consumer Past Experience and Moral Obligation Toward Buying Local Blueberries in Florida Within the Theory of Planned Behavior}

Built upon agrarian roots, America has been shaped by agriculture (Hamilton, 2004). Hurt (2002) estimated 75 to $90 \%$ of all colonists were engaged in farming around the time of the American Revolution. The extensive development of the agricultural sector during World War I and then World War II led the change from the family farm to an industrialized business, limited to those individuals with the means to participate in food production (Cochrane, 1993). "For most Americans, food today is just a product of the grocery store and farmers are an image in news about drought or disease - or television characters hocking cereals and orange juice" (Hamilton, 2004, p. 10).

However, a shift in the agricultural industry has occurred because consumers are becoming more engaged in the environment and the ways in which their food is produced (Schnell, 2013). Citizens have become more aware of their choices for food consumption and the ramifications those choices have on the environment (Kerton \& Sinclair, 2010). As a result, more consumers are interested in forming connections to how their food is grown, handled, and transported (Hamilton, 2004). Additionally, consumers have expressed concern over the quality and safety of their food after foodborne illnesses have been reported (Blake, Mellor, \& Cran, 2010). This consumer awareness movement has given rise to the way in which farmers communicate and interact with consumers about the food and goods they produce (Giovannucci, Barham, \& Pirog, 2010). With the growth of farmers selling their goods in a variety of outlets and the U.S. government's increased emphasis and attention given to locally grown food, researchers need to identify specific factors impacting how consumers internalize and form attitudes about their decisions to purchase locally grown food in order to inform further research and practice.

The term local has different definitions, and research has shown consumers are adaptive in their interpretation of what local means to them based on where they live and the types of foods available to them (Roper, Rumble, Ma, \& Irani, 2015). Based on consumers' locations, a certain fruit or vegetable may or may not be grown in their state or region; however, consumers are willing to expand their definition of "local" to encompass the closest available area to them for purchasing the product (Roper et al., 2015). Trivette (2015) posited the concept of local to be further defined by physical location and personal connection. Local by proximity refers to how many miles the food travels from producer to consumer; while, local by relationship adds the component of cultural and personal connection to a food (Trivette, 2015). Buying locally grown food has also been shown to have barriers and limitations for consumers. These barriers include location, amount of travel required, price, and convenience (Roper et al., 2015). Goodwin (2013) found Florida consumers held favorable attitudes toward buying local food, supporting the local economy through buying local foods, engaging with where their food was grown, and knowing how their food was grown, but had reservations. Key attributes impacting consumers' intention of buying local food included availability, price, convenience, trust of the farmer, and awareness (Goodwin, 2013).

Similarly, to organic food (Hughner, McDonagh, Prothero, Shultz, \& Stanton, 2007), consumers who purchase locally grown foods are willing to pay a premium price for high-quality food grown with less environmental impact such as minimal or no pesticide/herbicide use, no-till production methods, etc. (Martinez et al., 2010). Research has shown defining what local food is 
and is not is complicated at best and is a multifaceted concept linked to personal relationships, location, time, and financial constraints (Roper et al., 2015; Trivette, 2015).

In their research with organically grown, local food, Kerton and Sinclair (2010) found participants to have more meaningful and long-term thoughts and values related to where and how food is grown when given hands-on learning opportunities and additional information. "Having a connection to their food and to the producers of their food is an experience that inspired many of the other participants to take their learning and consumer behaviors one step further in reflecting on their values" (Kerton \& Sinclair, 2010, p. 411). Having a face-to-face interaction with the farmer was impactful to the participants' thoughts on the value of buying local, organic food; however, a greater impact was shown when the participants were able to engage in the day-to-day dealings of farm life (Kerton \& Sinclair, 2010). Similarly, community supported agriculture (CSA), a program designed to allow groups of citizens to buy a share within a farm in exchange for portions of the crop when available, has been found to potentially have a positive impact on participants' food sustainability choices and overall consumption of fresh foods, when the act of buying and receiving produce was partnered with educational components and receiving unfamiliar products within the CSA structure (Rossi, Allen IV, Woods, \& Davis, 2017). The repetitive nature and inherent qualities of the CSA model may encourage participants to engage in these behaviors. The same behaviors may not be present in other groups who are not given multiple opportunities to learn and experience different aspects of the agricultural and food production sectors (Rossi et al., 2017). The research by Rossi et al. (2017) highlighted the importance of consumers' past experience with buying, consuming, and overall familiarity on their future food consumption behaviors.

Other scholars have explored various ways in which social and moral factors influence consumers' decisions to buy and engage with local, organic, sustainable, and fair-trade products (Codron, Siriex, \& Reardon, 2006; Johnston \& Szabo, 2011; Johnston, Szabo, \& Rodney, 2011; Morgan, 2010; Peterson, 2013). Buying locally can be seen as an individual's commitment to participating in environmentally friendly behaviors for the social good, and may serve as an influence to others to participate in environmentally friendly ways (Peterson, 2013). When marketing niche foods, such as local, organic, fair-trade, etc., consumers' values are different across different populations and specific considerations for why and how consumers choose to engage with certain food products should be considered (Codron et al., 2006).

\section{Theoretical Framework}

Realizing consumers' interest in forming connections with where and how their food is grown (Hamilton, 2004; Kerton \& Sinclair, 2010; Schnell, 2013), communication practitioners and researchers need to be cognizant of why and how consumers are interested in buying local food when developing marketing and communication campaigns aimed at encouraging consumers to buy local food. The Theory of Planned Behavior seeks to predict, understand, and describe human behaviors and actions (Ajzen, 1991). The theory attempts to explain an individual's behavioral intent based on attitudes, beliefs, and subjective norms (Ajzen, 1991). Behavior intention can be determined using three factors related to an individual's beliefs: (a) attitude toward the behavior and behavioral beliefs; (b) subjective norms and normative beliefs - how the individual perceives the social expectations and norms for completing the behavior; and (c) perceived behavior control and control beliefs - how much control, over the task, an individual felt in completing the behavior (Ajzen, 1991; Mathieson, 1991). 
For this study, the Theory of Planned Behavior was identified as the most relevant model to use for predicting consumers' intention to buy locally grown food. However, with the insight of previous research and theoretical foundations, the Theory of Planned Behavior model's ability to predict consumer behavior has been shown to benefit from the inclusion of additional variables unique to the behavior in question. Research has shown the inclusion of a variable to account for past experience may increase the predictability of an individual's intent toward a behavior (Bentler \& Speckart, 1979; Eagly \& Chaiken, 1993; Fazio \& Zanna, 1978; Fazio, Chen, McDonel, \& Sherman, 1982; Glasman \& Albarracin, 2006). In a meta-analysis of how attitudes impact behavior, Glasman and Albarracin (2006) reported that direct experience was a contributing factor in an individual's attitude about performing a behavior. Additionally, Eagly and Chaiken (1993) compared and contrasted various models and indicated the Theory Planned Behavior's predictability was increased with the inclusion of the variable of past experience.

In a slightly different vein of research aimed at understanding consumers' buying behavior of food using the Theory of Planned Behavior, Kim, Jang, and Kim (2014) included the variable of ecological concerns to the original model and increased the predictability of consumers' intention of buying genetically modified foods. This variable was associated with consumers' ethical and environmental concerns related to buying genetically modified foods. The inclusion of additional variables to better address causal relationships and barriers to buying specific foods or goods has shown to increase the predictability of the Theory of Planned Behavior model (Kim et al, 2014; Shin, 2014; Dowd \& Burke, 2013).

Understanding several barriers exist with buying local food, the Theory of Planned Behavior may benefit from the addition of other variables to explain how these barriers interact with an individual's intent to buy local food. Additionally, research has shown how individuals internalize the importance of buying specific types of food, like organic and local, based on key attributes (Lee \& Yun, 2015). Carson et al. (2016) found face-to-face interactions with farmers at farmers' markets could impact purchasing behavior change on both a short and long-term basis. The interactions with farmers at farmers' markets was shown to impact more than the consumers' food choices, but also contributed to their perceptions of buying local food to support healthy living, a viable local economy, and environmentally sustainable behaviors (Carson et al., 2016). Therefore, research is needed to understand the specific attributes of local food consumers place value in, from a sociological and psychological perspective, with respect to their ability to predict intention to buy local food within the Theory of Planned Behavior.

The concept of adding additional variables to the Theory of Planned Behavior in research within the context of agricultural and environmental sciences has been met with some success. Arvola et al. (2007) studied the impact of adding the components of affective and moral attitudes into the model of Theory of Planned Behavior to predict buying intentions of organic foods and found the implementation of the constructs improved the model in some scenarios. By adding the component of moral feelings, the researchers were able to account for consumers behaving a certain way (Arvola et al., 2007). Similarly, the variable of moral obligation was shown to increase the predictability of the Theory of Planned Behavior in a study related to purchasing local food (Shin, 2014). Shin (2014) confirmed an individual's attitude toward a behavior and subjective norms, perceived behavioral control, and moral norms were significant predictors of behavioral intention; however, noted the need for future research to examine the inclusion of other variables.

With consumers' increased engagement with where and how their food is produced, exploring how the Theory of Planned Behavior can be utilized to predict intention to buy is of paramount 
importance to research. Specifically, exploring how the inclusion of additional variables can impact the predictability of the model is of significance to future research and practitioners.

\section{Purpose and Research Objectives}

The purpose of this research was to understand how consumers' intentions to buy local food, specifically blueberries from Florida, could best be predicted using the Theory of Planned Behavior with the inclusion of the variables of past experience buying local food and selfidentity/moral obligation toward buying local food.

For this study, the variable of self-identity/moral obligation was defined as how individuals' feelings about buying local food aligned with their moral obligation to the community, environment, and consumer behaviors. With a greater understanding of how an individual's past experience buying local food and his/her moral obligation toward buying local food impacts the Theory of Planned Behavior's predictability of intent, professionals and researchers within the field of communication can understand the needs and preferences of consumers and highlight those attributes of certain products to consumers. Additionally, since the past research has shown the definition of local to be ambiguous (Roper et al., 2015; Trivette, 2015), the current study focused on the single commodity of blueberries grown in Florida to remove potential mitigating variables.

The following research objectives were identified and used to guide the current research:

$\mathrm{RO}_{1}$ : Determine the effect the interaction between past experience and the individual variables within the Theory of Planned Behavior have on intent to buy local blueberries when controlling for self-identity/moral obligation toward buying local blueberries.

$\mathrm{RO}_{2}$ : Determine the effect the interaction between self-identity/moral obligation and the individual variables within the Theory of Planned Behavior have on intent to buy local blueberries when controlling for past experience buying local blueberries.

\section{Methods}

To address the current study's research objectives, an online survey was administered through Qualtrics. This research was part of a larger study and respondents were assigned to different treatment groups; however, the current study was only focused on all respondents' intent to purchase locally grown blueberries with regard to their past experience, self-identity/moral obligation, attitude, subjective norms, and perceived behavioral control toward buying local blueberries. The survey included bi-polar, semantic differential scales and Likert-type questions to assess the variables of interest. Questions revolved around the respondents' thoughts and experiences buying local food to establish their perceptions of buying local food, and specifically blueberries. An example of the 5-point Likert-type questions asked was: "Buying local food is important to me." The scale for these questions was: 1 (strongly disagree) and 5 (strongly agree). An example of the five-point, bi-polar, semantic differential scale was: "I believe buying local food is..." These questions were coded and analyzed with the negative adjective equal to 1 and the positive adjective equal to 5 .

The population for this study was determined to be all consumers within Florida. To determine an appropriate sample size, data from the U.S. Census Bureau was used, and the most up-to-date dataset indicated that the population for Florida was 18,801,310 (U.S. Census Bureau, 2014). Since

this current study was part of a larger research project, respondents were separated into distinct 
groups. In order to achieve a $95 \%$ confidence level interval for all groups, a minimum of 1,155 participants was needed. To ensure enough completed surveys, the sample size for the present study was $n=1,794$. An outside marketing firm was used to recruit participants to the study using the Internet and crowdsourcing techniques. Crowdsourcing uses the Internet to send out a generic request for a large population in exchange for monetary compensation (University of Waterloo, 2013). Crowdsourcing has become a popular method of recruiting participants to studies because of the Internet's prevalence in today's everyday life (Baker et al., 2013). Internet research has become an ever-increasing way of contacting and recruiting individuals to participate in research because of the way people choose to use and engage with the Internet (Baker et al., Ruggiero, 2000). According to the Pew Research Center (2018), 89\% of Americans use the Internet. It has also been noted landline phones are not the norm for most of today's households; thus, rendering random-digit-dialing methods of recruitment unreliable (Baker et al., 2013; Pew Research Center, 2018). Therefore, new methods of recruiting today's technologically connected individuals are needed. One of those methods is using opt-in panels with computer-mediated software and crowdsourcing sampling techniques (Baker et al., 2013).

Just as all probability-sampled studies are not inherently reliable, all studies that use nonprobability samples are not necessarily irrelevant. However, more responsibility is placed on the researcher to provide transparent methodological and sampling practices when reporting the study's findings (Baker et al., 2013). Several procedures can be implemented in studies with nonprobability samples to ensure the research is rigorous and reliable. The reliance on post-hoc adjustments using population data sets is one way to weight and increase the usability of the findings (Baker et al., 2013). Also, this study used the measure of coverage error to ensure the reliability of the results. The measure of coverage error was controlled by comparing the study's sample demographics to the U.S. Census Bureau's data for Florida (Baker et al., 2013).

Once recruited, this non-probability sample of respondents was given a link to an Internet survey created in Qualtrics. The survey contained several quality checks to ensure participants only completed the survey once, were thoroughly reading the survey questions, and were verifiable individuals and not computer-automated systems. The survey questions were adapted from previous studies (Brain 2008; Hrubes, Ajzen, \& Daigle, 2010; Osgood, Suci, \& Tannenbaum, 1978) and adapted by the researcher. Four expert researchers in public opinion, non-probability sampling, and communication examined the survey for face and content validity. The survey was pretested and pilot tested to ensure the survey accurately measured each variable and the survey was working properly on various Internet platforms. Each of the questions had a reliability of a Cronbach's Alpha of .78 or higher, which is acceptable (Field, 2009; Kirk, 2013).

These types of sampling and testing procedure do have several limitations that should be noted and recognized when analyzing the findings from this present study. The primary limitation to this study was the use of a non-probability sample which does not allow for generalizability of the findings to the entire population because not every individual within the population had an equal opportunity of being selected for the study (Baker et al., 2013; Field, 2009). However, the findings can be applied and expanded upon to other commodity research in the future (Baker et al., 2013).

Another limitation was delivery method of the survey. This survey was administered via the Internet and relied on crowdsourcing techniques. Therefore, the individuals who responded in this study were potentially different than those who did not have access to the Internet or chose not to respond to crowdsourcing techniques. The findings from this study should be applied with this limitation in mind; but this study does provide an opportunity for future research to be conducted 
to better understand the differences between those who respond to crowdsourcing techniques and those who do not.

Finally, the findings from this study are limited to buying blueberries grown in Florida, as that was the commodity used for the purposes of this study. To better measure perceived behavioral control, blueberries were used as the target commodity because they were in peak season and able to be recognized and purchased as a local food by respondents during the time of data collection (Ajzen, 2002). Research has shown the definition of local food is more abstract in some consumers' thinking (Giovannucci et al., 2010; Schnell, 2013); therefore, the current study chose to use a single commodity that is commonly known by Florida consumers to be grown locally. This was implemented in the design to mitigate any confusion when participants were responding to the questions and thinking about their purchasing habits of local food. Also, because past research has shown consumers are flexible in their definition of local food (Giovannucci et al., 2010; Schnell, 2013) respondents were given the definition of local food as being food grown in Florida to ensure consistent understanding of each question by respondents. These reliability measures created a limitation within the study, limiting the findings to only blueberries grown in Florida. Even with this limitation, the findings from this study could be beneficial for guiding future research and marketing decisions related to consumers buying local food.

The data were analyzed using SPSS 22.0 to address each of the research objectives. To properly analyze each of the research objectives, new interaction terms were created by averaging each variable and then multiplying the two indices. For each newly created interaction, a general linear model was performed, holding each control variable identified within the research objective constant. General linear is an extension of multiple regression, allowing for the introduction and analysis of multiple independent and dependent variables to give greater understanding to relationships (Kirk, 2013). An ANOVA was performed as a post-hoc analysis of the data and general linear regression test was performed on the Theory of Planned Behavior variables to test the strength of the model without the addition of variables.

A total of 1,794 respondents participated in the study; however, only 1,122 responses $(62.5 \%)$ were usable due to incomplete surveys or failed quality checks within the removed surveys. Of the respondents, $47.2 \%(n=530)$ were male, with $52.8 \%(n=592)$ were female. Respondents varied in age and ethnicity. Approximately $83 \%$ of respondents $(n=936)$ were white and $4.7 \%$ identified themselves as Hispanic/Latino in ethnicity. The demographics from this study were compared to the census data available for Florida and found to be not significant, with respect to coverage error (Baker et al., 2013).

\section{Results}

The first research objective examined the interaction between past experience and the variables of Theory of Planned Behavior (attitude toward the behavior, subjective norms, and perceived behavioral control) on intent to buy local blueberries when controlling for self-identity/moral obligation toward buying local food. Using a general linear model as an analysis of covariance the data were analyzed. It was found the interaction between respondents' past experience and attitude toward the behavior was a significant contributor to their intent to buy locally grown blueberries $\left(F_{53,1138}=5.26, p<.01\right)$ (Table 1$)$. The $\mathrm{R}^{2}$ was .402 ; therefore, the interaction accounted for $40.2 \%$ of the variance associated with intent to buy local blueberries, when controlling for selfidentity/moral obligation. 
Upon analysis, the interaction between respondents' past experience buying local food and their subjective norms was found to be a significant contributor to their intent to buy locally grown food $\left(F_{48}, 1138=6.32, p<.01\right)$ (Table 1$)$. The $\mathrm{R}^{2}$ was .41 ; therefore, the interaction accounted for $41 \%$ of the variance associated with intent to buy local blueberries, when controlling for selfidentity/moral obligation.

The interaction between respondents' past experience buying local food and their perceived behavioral control toward buying local food was a significant contributor to their intent to buy locally grown food $\left(F_{63,1138}=3.87, p<.01\right)$ (Table 1$)$. The $\mathrm{R}^{2}$ was found to be .387 ; therefore, the interaction between past experience and perceived behavioral control accounted for $38.7 \%$ of the variance associated with respondents' intent to buy locally grown blueberries when controlling for self-identity/moral obligation.

Table 1:

Interaction Between Past Experience, Self-Identity/Moral Obligation, Attitude Toward, Subjective Norms, and Perceived Behavioral Control Toward Buying Local Food

\begin{tabular}{|c|c|c|c|c|c|}
\hline Variable & $S S$ & $d f$ & $M S$ & $F$ & $p$ \\
\hline $\begin{array}{l}\text { Past Experience x Attitude Toward } \\
\text { Behavior }\end{array}$ & 93.98 & 53 & 1.77 & 5.26 & $<.01$ \\
\hline Error & 364.75 & 1083 & .33 & & \\
\hline Total & 18801.77 & 1138 & & & \\
\hline $\begin{array}{l}\text { Past Experience x Subjective } \\
\text { Norms }\end{array}$ & 100.08 & 48 & 2.08 & 6.32 & $<.01$ \\
\hline Error & 358.64 & 1088 & .33 & & \\
\hline Total & 18801.77 & 1138 & & & \\
\hline $\begin{array}{l}\text { Past Experience x Perceived } \\
\text { Behavioral Control }\end{array}$ & 84.99 & 63 & 1.34 & 3.87 & $<.01$ \\
\hline Error & 373.73 & 1079 & .34 & & \\
\hline Total & 18801.77 & 1138 & & & \\
\hline $\begin{array}{l}\text { Self-Id/Moral Obligation x } \\
\text { Attitude Toward Behavior }\end{array}$ & 206.55 & 110 & 1.87 & 5.59 & $<.01$ \\
\hline Error & 344.07 & 1026 & .33 & & \\
\hline Total & 18801.77 & 1138 & & & \\
\hline $\begin{array}{l}\text { Self-Id/Moral Obligation x } \\
\text { Subjective Norms }\end{array}$ & 224.51 & 81 & 2.77 & 8.96 & $<.01$ \\
\hline Error & 326.11 & 1055 & .30 & & \\
\hline Total & 18801.77 & 1138 & & & \\
\hline $\begin{array}{l}\text { Self-Id/Moral Obligation } \mathrm{x} \\
\text { Perceived Behavioral Control }\end{array}$ & 198.21 & 133 & 1.49 & 4.24 &.$<.01$ \\
\hline Error & 352.41 & 1003 & .35 & & \\
\hline Total & 18801.77 & 1138 & & & \\
\hline
\end{tabular}


The second research objective was created to determine the effect the interaction between selfidentity/moral obligation and the individual variables within the Theory of Planned Behavior (attitude toward the behavior, subjective norms, and perceived behavioral control) when controlling for past experience buying local food. Similar to the first research objective, individual interaction effects were examined with each of the three variables within the theory, holding past experience buying local food constant. The interaction between respondents' self-identity/moral obligation and attitude toward buying local blueberries was found to be a significant contributor to their intent to buy local food $\left(F_{110,1138}=5.59, p<.01\right)$ (Table 1$)$. Also, the $\mathrm{R}^{2}$ was shown to be .43 ; therefore, the interaction accounted for $43 \%$ of the variance associated with intent to buy local blueberries, when controlling for past experience.

The interaction between respondents' self-identity/moral obligation and subjective norms toward buying local food was found to be a significant contributor to their intent to buy locally grown food $\left(F_{81,1138}=8.96, p<.01\right)$ (Table 1$)$. Additionally, it was found that $46.5 \%$ of the variance associated with respondents' intent to buy locally grown blueberries was attributed to the interaction of their self-identity/moral obligation and their subjective norms toward buying local food when controlling for past experience $\left(\mathrm{R}^{2}=.465\right)$.

After analyzing the data, it was found the interaction between respondents' self-identity/moral obligation and perceived behavioral control toward buying local food was a significant contributor toward their intent to buy local food $\left(F_{133,1138}=4.24, p<.01\right)$ (Table 1$)$. The $\mathrm{R}^{2}$ was analyzed and it was found that $42.2 \%$ of the variance in the respondents' intent to buy locally grown food was associated with the interaction between their self-identity/moral obligation and perceived behavioral control toward buying local food, when controlling for past experience $\left(\mathrm{R}^{2}=.422\right)$.

Several post hoc analyses were completed to better understand the findings from this study. First, an ANOVA was used to analyze respondents' past experience buying local food and their intent to buy local blueberries. The variables within the Theory of Planned Behavior (attitude toward the behavior, subjective norms, and perceived behavior control) were used compared to respondents' past experience buying local food and then to their self-identity/moral obligation toward buying local food. A significant relationship was found between past experience and their intent to buy local food $\left(F_{4,1138}=35.73, p<.01\right)$; however, $11.2 \%$ of the variance associated with respondents' intent to buy local blueberries was attributed to their past experience buying local food. Also, it was found that respondents' self-identity/moral obligation toward buying local food was significantly related to their intent to buy local blueberries $\left(F_{1,1138}=258.683, p<.01\right)$; however, $27.7 \%$ of the variance associated with respondents' intent to buy local food was attributed to their self-identity/moral obligation of buying local food.

Finally, the Theory of Planned Behavior model variables (attitude toward the behavior, subjective norms, and perceived behavioral control) were analyzed with an ANOVA to determine respondents' intent to buy local blueberries. The post-hoc analysis was used to determine if the model was more appropriate for understanding the respondents' intention to buy locally grown blueberries without the inclusion of the variables of past experience and self-identity/moral obligation toward buying local food. The model was found to be significant $\left(F_{3,1125}=174.30, p<\right.$ $.01)$ in predicting respondents' intention to buy locally grown food; however, the variance associated with respondents' intent attributed to the variables of attitude, subjective norms, and perceived behavioral control toward buying local food was $31.8 \%$; therefore, the inclusion of the interactions between past experience and self-identity/moral obligation increased the $\mathrm{R}^{2}$ and explained more of the variance associated with respondents' intent to buy locally grown food. 


\section{Conclusions}

Based on the findings from this study, the variables within in the Theory of Planned Behavior did contribute to respondents' intent to buy locally grown blueberries. However, it should be noted including the variables of past experience and self-identity/moral obligation toward buying local blueberries strengthened the predictability of intention within the model. Including the variable of past experience validated Bentler and Speckart's model (1981), in which past behavior was included within the Theory of Planned Behavior to better predict intention.

Based on the findings from this study, the Theory of Planned Behavior's predictability of intention was strengthened with the addition of the variables of past experience and selfidentity/moral obligation toward buying locally grown blueberries. As explained by Eagly and Chaiken (1993), Fishbein and Ajzen omitted an individual's personal beliefs from their Theory of Planned Behavior because those beliefs are too confounded by other variables within behavioral intention that the addition of a variable to account for an individual's personal beliefs does not add to the predictability of an individual's intent. This study indicated the addition of an individual's self-identity/moral obligation toward buying locally grown blueberries may be an important variable to consider when investigating communication practices related to promoting local food to consumers. Unlike the findings of Brain's (2008) research related to conservation practices in agriculture, the current study's data suggested that measuring and accounting for an individual's perceived self-identity/moral obligation toward buying locally grown blueberries is impactful. This finding, in the current research, suggests including the variable of moral obligation may increase predictability of intention to complete a behavior. While eating locally may not be viewed as a moral obligation in some contexts (Peterson, 2013), the current study highlights it may be relevant for research related to buying locally grown food. Why and how consumers choose to buy food is a complex process to untangle; however, the current study adds to the body of literature identifying elements that may influence how and where consumers align their food choices and social values within their buying behaviors (Codron et al., 2006).

Also, when using the Theory of Planned Behavior, researchers should seek to understand if the behavior is related to the individual's self-identity. As Eagly and Chaiken (1993) discussed, several additional variables may improve the Theory of Planned Behavior's predictability depending on the nature of the behavior. Therefore, when conducting research in communication using the Theory of Planned Behavior, researchers should take into account how an individual aligns themselves within society, and how they want to be seen in society when predicting intention toward buying locally grown food.

The researchers recommend more research be conducted using the Theory of Planned Behavior to understand how it relates to consumer intention and action toward buying local food to connect consumers with those who produce their food. Future research should be conducted to determine if the inclusion of variables, such as past experience and self-identity/moral obligation, are key to predicting consumer intention, with respect to buying locally grown commodities. Variables to consider in the future could be: community and economic development efforts, supporting local farmers, or environmental engagement. Also, the Theory of Planned Behavior should be examined beyond intention and measure actual behavior. This study only examined respondents' intention to buy locally grown blueberries; however, the Theory of Planned Behavior does account for actual completion of a behavior (Ajzen, 2011; Ajzen \& Fishbein, 1980). Also, the current study only examined the commodity of Florida-grown blueberries. Future research should focus on 
understanding if the findings from this study are similar when applied to another commodity or in another state.

Self-identity/moral obligation was shown to be a significant predictor of consumer intention to purchase locally grown blueberries in this study. Future research should examine how consumers' self-identity/moral obligation toward buying local food can be increased in individuals to encourage them to buy local food. Consumers' desire to buy local food has been linked to supporting the local economy and directly connecting themselves with their food (Blake et al., 2010; Carpio \& Isengildina-Massa, 2009; Giovannucci et al., 2010; Onken \& Bernard, 2010; Schnell, 2013). Therefore, future research should focus on understanding the extent to which individuals' self-identity/moral obligation towards buying local food drives their intent and action in buying local food. Research has shown specific barriers associated with individuals' buying local food, including price, convenience, and travel (Roper et al., 2015). However, future research should focus on discovering other variables that may override those barriers, including an individual's self-identity/moral obligation toward buying local food. In addition, research should be conducted to learn the best way to form and align the practice of buying local food to an individual's self-identity/moral obligation. Research focused on enhancing an individual's moral obligation toward buying local food may be beneficial to the future marketing of local food.

From a theoretical perspective, the findings from the current study highlight the complexity of understanding why respondents chose to buy local blueberries. The current study shows the importance of trying to identify variables outside of the Theory of Planned Behavior that may contribute to an individual's intent to buy local. While the Theory of Planned Behavior was a useful model in predicting the respondents' intention toward the behavior of buying local blueberries, other theories and models must be considered to understand the most effective way to communicate, educate, and engage consumers about buying local food and engaging them in learning about where and how their food is grown and produced. Buying local food supports local economies and has been shown to increase healthy eating habits of fresh fruits and vegetables (Kerton \& Sinclair, 2010; Schnell, 2013); thus, local food is an important initiative to share with consumers.

For application and implementation, the results of this study indicated consumers are driven to buy local food if it aligns with their self-identity and moral obligation. Therefore, communication professionals should use language and messages that connect local food and the community to the consumer. Messages should be developed to appeal to consumers' sense of community and enhancement of their surrounding area. Potential messages make consumers feel that their purchase of local food is important to community development, creating a healthy infrastructure, and promoting healthy living for future generations. Based on the questions used in this survey, buying local food, specifically blueberries was important to people, and respondents were willing to devote some of their money to buying local blueberries if they had it available; therefore, messages should appeal to this moral obligation of consumers in the future.

Finally, past experience buying local food was indicative of respondents' intent to buy local food in the future throughout this study. Professional communicators need to recognize that every encounter consumers have with buying local food is imperative to their future buying intentions of local food (Rossi et al., 2017). Similar to Carson et al. (2016), consumers' experiences at farmers' markets buying local food indicated an impact on short and long-term buying behaviors of local blueberries, the current study indicates every interaction with local food has the power to impact future buying behavior. Also, practitioners should work to continue to form direct connections between consumers and those who produce their food. Again, forming the direct 
connection between consumers and farmers has the ability to impact consumers' selfidentity/moral obligation to buy local food, but also past experience has a direct connection on buying local food in the future. The concept of engaging consumers in the food they choose to buy and consume is of paramount importance now and in the future. Today's actions and decisions by consumers, from an economical and legislative standpoint, impact the future of the food industry of the future. Encouraging and fostering the connection between consumers and those who grow and produce their food is of utmost importance for communication professionals and researchers.

Ajzen, I. (2011). The theory of planned behavior: Reactions and reflections. Psychology \& Health, 26(9), 1113-1127. doi:10.1080/08870446.2011.613995

Ajzen, I. (2002). Perceived behavior control, self-efficacy, local of control, and the theory of planned behavior. Journal of Applied Social Psychology, 32(4), 665-683. doi:10.111/j.15591816.2002.tb00236.x

Ajzen, I. (1991). The theory of planned behavior. Organizational Behavior and Human Decision Processes, 50(2), 179-211. doi:10.1016/07449-5979(91)90020-T

Ajzen, I., \& Fishbein, M. (1980). Understanding attitudes and predicting social behavior. Englewood Cliffs, N.J.: Prentice-Hall, Inc.

Arvola, A., Vassallo, M., Dean, M., Lampila, P., Saba, A., Lahteenmaki, L., \& Shepherd, R. (2007). Predicting intentions to purchase organic food: The role of affective and moral attitudes in the theory of planned behavior. Appetite, 50(2-3), 443-454. doi:10.1016/j/appet.2007.09.010

Baker, R., Brick, J. M., Bates, N. A., Battaglia, M., Couper, M. P., Dever, J. A., Gile, K. J., \& Torangeau, R. (2013). Report of the AAPOR Task Force on non-probability sampling. Journal of Survey Statistics and Methodology, 1(2), 90-143. doi:10.1093/jssam/smt008

Bentler, P. M., \& Speckart, G. (1979). Models of attitude-behavior relations. Psychological Review, 86(5), 454-464. doi:10.1037/0033-295X.86.5.452

Bentler, P. M., \& Speckart, G. (1981). Attitudes “cause" behaviors: A structural equation analysis. Journal of Personality and Social Psychology, 40(2), 226-238. doi:10.1037/00223514.40.2.226

Blake, M. K., Mellor, J., \& Crane, J. (2010). Buying local food: Shopping practices, place, and consumption networks in defining food as "local". Annals of the Association of American Geographers, 100(2), 409-426. doi:10.1080/00045601003595545

Brain, R. G. H. (2008). Predicting engagement in a conservation easement agreement (Doctoral Dissertation). Retrieved from ETD Theses and Dissertations http://etd.fcla.edu/UF/UFE0023555/brain_r.pdf

Carpio, C. E., \& Isengildina-Massa, O. (2009). Consumer willingness to pay for locally grown products: The case of South Carolina. Agribusiness, 25(3), 412-426. doi:10.1002agr.20210

Carson, R. A., Hamel, Z., Giarrocco, K., Baylor, R., \& Greden Mathews, L. (2016). Buying in: the influence of interactions at farmers' markets. Agriculture \& Human Values, 33(4), 861875. doi:10.1007/s10460-015-9675-y

Cochrane, W. W. (1993). The development of American agriculture: A historical analysis. Minneapolis, MN: University of Minnesota Press. 
Codron, J. M., Siriex, L., \& Reardon, T. (2006). Social and environmental attributes of food products in an emerging mass market: Challenges of signaling and consumer perception, with European illustrations. Agriculture and Human Values, 23(3), 2830297. doi:10.1007/s10460-006-9000-x

Eagly, A. H., \& Chaiken, S. (1993). The psychology of attitudes. Belmont, CA: Wadsworth Group/Thomas Learning, Inc.

Fazio, R. H., Chen, J., McDonel, E. C., \& Sherman, S. J., (1982). Attitude accessibility, attitudebehavior consistency, and the strength of the object-evaluation association. Journal of Experimental Social Psychology, 18(4), 339-357. doi:10.1016/0022-1031(82)90058-0

Fazio, R. H., \& Zanna, M. P. (1978). Attitudinal qualities relating to the strength of the attitudebehavior relationship. Journal of Experimental Social Psychology, 14(4), 398-408. doi.10.1016/0022-1031(78)90035-5

Field, A. (2009). Discovering statistics using SPSS (3 $\left.{ }^{\text {rd }}\right)$. Thousand Oaks, CA: Sage Publications, Inc.

Glasman, L. R., \& Albarracin, D. (2006). Forming attitudes that predict future behavior: A metaanalysis of the attitude-behavior relation. Psychological Bulletin, 132(5), 778-822. doi:10.1037/0033-2909.132.5.778

Giovannucci, D., Barham, E., \& Pirog, R. (2010). Defining and marketing "local" foods: Geographical indication for US products. The Journal of World Intellectual Property, 13(2), 94-120. doi:10.111/j.1747-1796.2009.00370.x

Goodwin, J. N. (2013). Local choice (Research Report). Retrieved from Center for Public Issues Education in Agriculture and Natural Resources Website: http://www.piecenter.com/wpcontent/uploads/2014/05/FDACS-Local-Choice-Report-FINAL.pdf

Hamilton, N. (2004). Essay - food democracy and the future of American values. Drake Journal of Agricultural Law, 9(1), 9-31. Retrieved from

http://heinonline.org/HOL/Page?handle=hein.journals/drag19\&div=8\&g_sent=1\&collection= journals

Hrubes, D., Ajzen, I., \& Daigle, J. (2010). Predicting hunting intentions and behavior: An application of the theory of planned behavior. Leisure Sciences: An Interdisciplinary Journal, 23(3), 165-178. doi:10.1080/014904001316896855

Hughner, R. S., McDonagh, P., Prothero, A., Shultz, C. J. II, \& Staton, J. (2007). Who are organic food consumers? A compilation and review of why people purchase organic food. Journal of Consumer Behavior, 6(2-3), 94-110. doi:10.1002/cb210

Hurt, D. R. (2002). American agriculture a brief history. West Lafayette, IN: Purdue University Press.

Johnston, J., \& Szabo, M. (2011). Reflexivity and the Whole Foods Market consumer: the lived experience of shopping for change. Agriculture and Human Values, 28(3), 303-319. doi:10.1007/s10460-010-9283-9

Johnston, J., Szabo, M., \& Rodney, A. (2011). Good food, good people: Understanding the cultural repertoire of ethical eating. Journal of Consumer Culture, 11(3), 293-318. doi:10.1177/1469540511417996

Kerton, S., \& Sinclair, J. A. (2010). Buying local organic food: A pathway to transformative learning. Agriculture and Human Values, 27(4), 401-413. doi:10.1007/s10460-009-9233-6

Kirk, R. E. (2013). Experimental design: Procedures for the behavioral sciences $\left(4^{\text {th }}\right)$. Thousand Oaks, CA: Sage Publications, Inc. 
Lee, H. J., \& Yun, Z. S. (2015). Consumers' perceptions of organic food attributes and cognitive and affective attitudes as determinants of their purchase intentions toward organic food. Food Quality and Preference, 39, 259-267. doi:10.1016/j.foodqual.2014.06.002

Martinez, S., Hand, M., Da Pra, M, Pollack, S., Ralston, K., Smith, T., ... Newman, C., (2010). Local foods systems concepts, impacts, and issues (Report No. 97). Retrieved from http://extension.missouri.edu/jefferson/documents/Local Food Systems Concepts Impacts and Issues.pdf

Mathieson, K. (1991). Predicting user intentions: Comparing the technology acceptance model with the theory of planned behavior. Information Systems Research, 2(3), 173-191. doi:10.1287/isre.2.3.173

Morgan, K. (2010). Local and green, global and fair: the ethical foodscape and the politics of care. Journal of Environment and Planning, 42(8), 1852-1867. doi:10.1068/a42364

Onken, K .A., \& Bernard, J C. (2010). Catching the "local" bug: A look at state agricultural marketing programs. Choices, 25(1), 1-7. Retrieved from http://www.choicesmagazine.org/magazine/article.php?article $=112$

Osgood, C. E., Suci, G. J., \& Tannenbaum, P. H. (1978). The measurement of meaning. Urbana, IL: University of Illinois Press.

Peterson, G.R. (2013). Is eating locally a moral obligation? Journal of Agricultural and Environmental Ethics, 26(2), 421-437. doi:10.1007/s10806-012-9397-8

Pew Research Center. (2018). Internet/Broadband fact sheet. Retrieved from: http://www.pewinternet.org/fact-sheet/internet-broadband/

Roper, C. G., Rumble, J. N., Ma, Y., \& Irani, T. A. (2015). Talking local: Florida consumer definitions of local food (\#AEC509). Gainesville: University of Florida Institute of Food and Agricultural Sciences. Retrieved from http://edis.ifas.ufl.edu/DLN

Rossi, J., Allen IV, J. E., Woods, T. A., \& Davis, A. F. (2017). CSA shareholder food lifestyle behaviors: a comparison across consumer groups. Agriculture and Human Values, p. 1-15. doi:10.1007s 10460-017-9779-7

Ruggiero, T. E. (2000). Uses and gratifications theory in the $21^{\text {st }}$ century. Mass Communication and Society, 3(1), 3-37. doi:10.1207/S15327825MCS0301_02

Schnell, S. M. (2013). Deliberate identities: Becoming local in America in a global age. Journal of Cultural Geography, 30(1), 56-89. doi:10.1080/08873631.2012.745984

Shin, Y. H. (2014). Local food purchase behavior of U.S. consumers: Application of an extended theory of planned behavior and self-congruity theory. (Doctoral Dissertation). Retrieved from https://shareok.org/bitstream/handle/11244/15122/Shin_okstate_0664D_13187.pdf?sequence $=1$

Trivette, S. A. (2015). How local is local? Determining the boundaries of local food in practice. Agriculture and Human Values, 32(3), 475-490. doi:10.1007/s10460-014-9566-7

University of Waterloo (2013). Human participant research guidelines: Use of crowdsourcing services. Retrieved from https://uwaterloo.ca/research/sites/ca.research/files/uploads/files/crowdsourcing_guidelines_a ccess_check_done.pdf

U.S. Census Bureau (2014). Profile of general population and housing characteristics: 2010 demographic profile data. Retrieved from http://factfinder2.census.gov/

USDA-AMS (2013). Farmers markets and local food marketing. Retrieved from http://www.ams.usda.gov/AMSv1.0/farmersmarkets 


\section{ABOUT THE AUTHORS}

Jessica Holt is an assistant professor in the Department of Agricultural Leadership, Education, and Communication at the University of Georgia.

Joy Rumble is an assistant professor in the Department of Agricultural Education and Communication at the University of Florida and works within Center for Public Issues Education in Agriculture and Natural Resources (PIE Center).

Ricky Telg is a professor in the Department of Agricultural Education and Communication and the director of the Center for Public Issues Education in Agriculture and Natural Resources (PIE Center) at the University of Florida.

Alexa Lamm is an associate professor in the Department of Agricultural Leadership, Education and Communication at the University of Georgia and works within the Office of Learning and Organizational Development. 